\title{
RESPONSES OF NORMAL AND MALIGNANT CELLS TO COLLAGEN, COLLAGEN-DERIVED PEPTIDES AND THE C5-RELATED TUMOR CELL CHEMOTACTIC PEPTIDE
}

\author{
JOHN A. WASS ${ }^{1}{ }^{*}$, JAMES VARANI ${ }^{1}$, GERALD E. PIONTEK ${ }^{1}$, PETER A. WARD ${ }^{1}$ and F. WILLIAM ORR ${ }^{2}$ \\ ${ }^{1}$ Department of Pathology, University of Michigan Medical School, Ann Arbor, MI 48109, U.S.A.; and \\ ${ }^{2}$ Department of Pathology, University of Manitoba Medical School, Winnipeg, Manitoba, Canada
}

(Accepted 14 August 1981)

\begin{abstract}
Two variant subpopulations of murine fibrosarcoma cells that differ significantly in their malignant potential and normal mouse fibroblasts were compared with regard to ability to respond chemotactically to collagen, collagen-derived peptides and the $\mathrm{C5}$-derived tumor cell chemotactic peptide. Two distinct patterns of responsiveness were observed. The normal fibroblasts and non-metastasizing fibrosarcoma cells responded to the collagen products but not the C5 peptide. The metastasizing fibrosarcoma cells responded to the C5 peptide but not to the collagen products. These findings emphasize the similarities between the normal fibroblasts and the non-metastasizing fibrosarcoma cells.
\end{abstract}

fibrosarcoma cells fibroblasts metastases collagen peptide C5 chemotactic peptide chemotaxis

\section{Introduction}

We have previously reported that a number of tumor cell lines, including the Walker 256 carcinosarcoma, the Novikoff hepatoma, a murine mastocytoma and a murine lymphoblastoid line, all demonstrate chemotactic responsiveness to a produce of the fifth complement of component (C5) (Romualdez and Ward, 1975, 1976; Romualdez et al., 1976; Orr et al., 1978a, b). In a recent study it was shown that a spontaneously metastasizing murine fibrosarcoma variant also responded chemotactically to the C5 factor but that a non-metastasizing variant isolated from the same tumor did not. Like the non-metastasizing fibrosarcoma cells, normal mouse fibroblasts also failed to respond to the chemotactic factor (Orr et al., 1981).

In the present study the chemotactic response of these same metastasizing and non-

\footnotetext{
* To whom all correspondence should be addressed.
}

metastasizing fibrosarcoma cells and normal fibroblasts to collagen and collagen degradation products was examined and compared with the response to the $\mathrm{C5}$ chemotactic peptide. The results indicate two distinct patterns of differentiation. In one pattern, exhibited by the normal fibroblasts and non-metastasizing fibrosarcoma cells, response to the collagen peptides but not the C5 peptide occurs. In the other pattern, exhibited by the metastasizing fibrosarcoma cells, response to the C5 peptide but not the collagen peptides occurs.

\section{Materials and methods}

\subsection{Cells}

The cells used in this study included high and low malignant fibrosarcoma lines obtained from a murine fibrosarcoma induced with 3-methylcholanthrene in a $\mathrm{C57Bl} / 6$ mouse. The origin and characteristics of these 
lines have been described previously (Orr et al., 1978a; Varani et al., 1979). Normal mouse embryo fibroblasts were also used in this study. They were obtained in suspension from Microbiological Associates (Bethesda, MD). Upon arrival in the laboratory they were plated in plastic flasks and used during the first passage. All of the cells were grown on medium 199 supplemented with $10 \%$ fetal calf serum, 100 units $/ \mathrm{ml}$ of penicillin and 100 $\mu \mathrm{g} / \mathrm{ml}$ of streptomycin. The tumor cells were routinely subcultured by trypsinization. However, for assay purposes the cells were obtained by washing in cold Hanks' balanced salt solution (HBSS) and vigorously shaking the flasks.

\subsection{Chemotactic factors}

Lathyritic chick collagen chains were kindly supplied by Dr. Arnold Postlethwaite of the Veterans Administration Hospital; Memphis, TN. They were originally prepared as described elsewhere (Postlethwaite et al., 1978) and solubilized by dissolving in $0.5 \mathrm{M}$ acetic acid $\left(37^{\circ} \mathrm{C}\right)$ to a concentration of $5 \mathrm{mg} / \mathrm{ml}$. The solution was then dialyzed at room temperature against phosphate-buffered saline for 2 days with frequent changes of buffer. The solubilized collagen was then stored at $-20^{\circ} \mathrm{C}$ until use.

These synthetic collagen peptides, glycyl-Lpropyl-L-hydroxyproline (GPH), glycyl-L-hydroxyproline $(\mathrm{GH})$ and L-prolylhydroxy-Lproline (PHP) were purchased from Sigma Chemical Company (St. Louis, MO) and prepared as $10^{-3} \mathrm{M}$ solutions in dimethyl sulfoxide. Final dilutions were made in HBSS.

The C5-related chemotactic factor was prepared as previously described from zymosanactivated normal human serum (Nilsson et al., 1972). The material with chemotactic activity

\section{TABLE I}

Responses of metastasizing and non-metastasizing fibrosarcoma cells and normal fibroblasts to collagen, collagen peptides and the C5-related tumor cell chemotactic factor

Chemotactic factor Responses in the Boyden chamber assay ${ }^{a}$ and particle counter assay ${ }^{b}$

\begin{tabular}{llllll}
\hline $\begin{array}{l}\text { Metastasizing } \\
\text { fibrosarcoma }\end{array}$ & \multicolumn{2}{l}{$\begin{array}{l}\text { Non-metastasizing } \\
\text { fibrosarcoma }\end{array}$} & \multicolumn{2}{l}{$\begin{array}{l}\text { Normal mouse } \\
\text { fibroblasts }\end{array}$} & \\
\cline { 2 - 4 } $\begin{array}{l}\text { Boyden } \\
\text { chamber }\end{array}$ & $\begin{array}{l}\text { Particle } \\
\text { counter }\end{array}$ & $\begin{array}{l}\text { Boyden } \\
\text { chamber }\end{array}$ & $\begin{array}{l}\text { Particle } \\
\text { counter }\end{array}$ & $\begin{array}{l}\text { Boyden } \\
\text { chamber }\end{array}$ & $\begin{array}{l}\text { Particle } \\
\text { counter }\end{array}$
\end{tabular}

Lathyritic chick

counter

chamber counter collagen $(1 \mathrm{mg} / \mathrm{ml}$ )

GPH $\left(10^{-8} \mathrm{M}\right)$

GH $\left(10^{-8} \mathrm{M}\right)$

$\operatorname{PHP}\left(10^{-8} \mathrm{M}\right)$

C5-derived factor

(1 $\mathrm{ED}_{50}$ )
0

$2 \pm 1$

$1 \pm 1$

0

$25 \pm 2$

$17 \pm 2$
$18 \pm 2$

$19 \pm 3$

$25 \pm 2$

$1 \pm 2$

$2 \pm 2$

a The Boyden chamber was run as described in our recent report (Orr et al., 1978a). Values represent the average number of cells ( \pm S.E.M.) counted in each of the three high power fields in each of three membranes. The number of cells counted in chambers to which HBSS alone was added have been subtracted. This value was normally between 15 and 25 cells per high power field. Each cell type was assayed in at least three occasions. One such experiment is shown.

b The particle counter assay was run as described in our recent reports (Wass et al., 1980, 1981). Values represent the maximum percent drop ( \pm S.E.M.) in the number of cells counted by the particle counter. Each value is the average of four experiments and in each experiment three values were obtained per point. Along with each treated sample of cells was run a sample of untreated cells. 
for leukocytes was treated by short-term trypsinization to produce maximal activity for the tumor cells (Orr et al., 1978a).

\subsection{Analytical methods}

The standard Boyden chamber chemotaxis assay was performed as previously described (Orr et al., 1978a). In addition to using the standard Boyden chamber method, we also used a particle counter assay to measure the interaction between the tumor cells and chemotactic factors. This assay is based on the finding that tumor cell swelling occurs in response to the chemotactic factors and that simultaneous to the swelling (and perhaps as a result of swelling) the number of cells in suspension counted by a particle counter temporarily decreases (Wass et al., 1980, 1981).

\section{Results}

Table I shows the pattern of responsiveness of all three cell types to the collagen-derived and C5-derived chemotactic peptides. It can be seen that the normal fibroblasts and nonmetastasizing fibrosarcoma cells had a similar pattern of responsiveness. Both responded to the lathyritic chick collagen and to the collagen-derived peptides, GPH and GH, but did not respond to the $C 5$ peptide. On the other hand, the metastasizing fibrosarcoma cells responded to the $\mathrm{C} 5$ peptide but did not respond to the collagen or collagen-related peptides. None of the cells responded to PHP. It can also be seen in Table I that the results obtained with the two assays were consistent with one another.

\section{Discussion}

Several studies have shown that normal human fibroblasts are able to respond chemotactically to collagen-derived peptides as well as to a number of other factors (Postlethwaite et al., 1976, 1978, 1979; Chiang et al., 1978, Postlethwaite and Kang, 1980). The present study demonstrates that normal mouse fibroblasts are also capable of responding to the same collagen-derived peptides. In addition, it was found in this study that a non-metastasizing line of murine fibrosarcoma cells also responded to these factors. In contrast, neither the normal fibroblasts nor the non-metastasizing fibrosarcoma cells demonstrate responsiveness to the $\mathrm{C5}$-derived tumor chemotactic peptide. The similarities between the normal fibroblasts and the low malignant fibrosarcoma cells in their responses to various chemotactic peptides would suggest some common membrane features. Whether the positive responses to the collagen peptides is only a marker of the 'normal' fibroblast surface or whether it has biological significance remains to be seen. It has been argued that the chemotactic response of normal fibroblasts to collagen contributes to the localization of fibroblasts at sites of wound healing (Postlethwaite et al., 1978). It could likewise be argued that the ability of the non-metastasizing tumor cells to respond to the collagen products may contribute to the prevention of their metastasizing. The universal presence of collagen throughout the body would desensitize the cells.

The lack of response of the metastasizing tumor cells to the collagen peptides and their positive response to the $\mathbf{C 5}$ peptide indicate a clear functional difference between these cells on the one hand, and the non-metastasizing fibrosarcoma cells and normal fibroblasts on the other. Whether this functional difference is a result of a major membrane alteration or of a subtle alteration in structure remains to be seen. With regard to chemotactic responsiveness, the metastasizing fibrosarcoma cells are very similar to polymorphonuclear leukocytes (Fernandez et al., 1978). It has been argued that the response to C5-derived peptides contributes to the ability of these cells to metastasize in the same manner as the response in leukocytes contributes to their ability to localize at sites of inflammation.

Whatever the biological significance of 
these chemotactic responses, the patterns of responsiveness exhibited by the normal fibroblasts and the metastasizing and non-metastasizing fibrosarcoma cells clearly indicate two pathways of differentiation. They clearly indicate that, in this regard, the low malignant, non-metastasizing fibrosarcoma cells have much more in common with the normal fibroblasts than with the highly malignant metastasizing fibrosarcoma cells obtained from the same parent tumor.

\section{Acknowledgement}

This study was supported by grant numbers CA29550, CA29551 and CA09205 from the National Institutes of Health.

\section{References}

Chiang, T.M., A.E. Postlethwaite, E.H. Beachey, J.M. Seyer and A.H. Kang: J. Clin. Invest. 62, 916 (1978).

Fernandez, H.N., P.M. Henson, A. Otani and T.E. Hugli : J. Immunol. 120, 109 (1978).
Nilsson, V.R., R.H. Toman and F.G. Taylor: Immunochemistry 9, 709 (1972).

Orr, W., J. Varani and P.A. Ward: Am. J. Pathol. 93, 405 (1978a).

Orr, W., S.H. Phan, J. Varani, P.A. Ward, D.L. Kreutzer, R.O. Webster and P.M. Henson: Proc. Natl. Acad. Sci. U.S.A. 76, 1986 (1978b).

Orr, F.W., J. Varani, J. Delikatny, N. Jain and P.A. Ward: Am. J. Pathol. 102, 160 (1981).

Postlethwaite, A.E., R. Syndermann and A.H. Kang: J. Exp. Med. 144, 1188 (1976).

Postlethwaite, A.E., J.M. Seyer and A.H. Kang: Proc. Natl. Acad. Sci. U.S.A. 75, 871 (1978).

Postlethwaite, A.E., R. Snyderman and A.H. Kang: J. Clin. Invest. 64, 1379 (1979).

Postlethwaite, A.E. and A.H. Kang: J. Immunol. 124, $1462(1980)$.

Romualdez, A.G. and P.A. Ward: Proc. Natl. Acad. Sci. U.S.A. 172, 4128 (1975).

Romualdez, A.G. and P.A. Ward: In: Membranes and Neoplasmin - New Approaches and Strategies. Progress in Clinical and Biological Research, ed. V.T. Marches (Alan R. Liss) Vol. 9 (1976).

Romualdez, A.G., P.A. Ward and T. Torikata: J. Immunol. 117, 1762 (1976).

Varani, J., W. Orr and P.A. Ward: Cancer Res. 39, 2376 (1979).

Wass, J.A., J. Varani and P.A. Ward: Cancer Lett. 9, 313 (1980).

Wass, J.A., J. Varani, G.E. Piontek, D. Goff and P.A. Ward: J. Nat. Cancer Inst. 66, 927 (1981). 